\title{
Africa and Pandemics
}

\author{
Towards a Regional Health Security Regime
}

Mutoy Mubiala*

\section{Introduction ${ }^{1}$}

African regional and sub-regional organizations have played an important role in the development of a regional approach to international law. This relates to most fields of this discipline, including international health law. This article examines the institutional aspects of African regionalism in this field at both sub-regional and regional levels. In particular, the article examines and evaluates the respective roles of the Regional Economic Communities, with special reference to the Economic Community of West African States (EcOWAS) specialized health agency, the West African Health Organization (WAHO) and the African Union (AU) Centre for Disease Control and Prevention (Africa CDC) in their responses to the recent pandemics, including the Ebola outbreaks in West Africa (2014-2016) and the Democratic Republic of the Congo (DRC), as well as their intervention in the context of the CoviD-19 pandemic.

The article evaluates their contribution to the development of a regional health security regime and to the implementation of the emerging African principle of "Responsibility to assist" (neologism) in the context of the abovementioned pandemics. The paper also examines how African regional human rights mechanisms have addressed the human rights challenges faced by African States in the same context, with special attention to the promotional activities of the African Commission on Human and Peoples' Rights. The paper respectively addresses the normative, institutional and operational aspects of the emerging African health security regime.

* Associate Professor of International Law, University of Kinshasa (DRC), Consultant, and former staff member (retired) of the United Nations.

1 See, in other contributions by the same author on the role of international law in pandemic responses, with special reference to the African region, Mutoy Mubiala, 'Le rôle des organisations régionales africaines dans la lutte contre les pandémies', in Société Francaise Pour Le Droit International, Santé et droit international, Colloque de Rennes, Paris, Pedone, 2019, 407-431; Id., 'The African Union and the Covid-19 Pandemic', Policy Brief No. 108, Brussels, TOAEP, 4 June 2O2O, 1-4; and Id., 'La 'responsabilité d'assister' et sa mise en œuvre dans la lutte contre les pandémies en Afrique', in African Yearbook of International Law/Annuaire africain de droit international, vol. 24, 2019/2020 (forthcoming). 
Before the creation of the African Union (AU) in 200o, the Organization of African Unity (OAU), which preceded it, was concerned with the fight against pandemics in Africa. The OAU focused on discussions and the adoption of declarations aimed at addressing three main pandemics affecting Africa, including $\mathrm{HIV} / \mathrm{AIDS}$, malaria and tuberculosis. After succeeding the OAU in 2002, the AU continued its normative action on the three diseases while developing new normative rules and guidance in the context of responses to the recent Ebola and Covid-19 pandemics in Africa.

\subsection{The Organization of African Unity (OAU)}

On 4 June 1997, as part of its normative action, the OAU adopted the Harare Declaration on Malaria Prevention and Control in the Context of African Economic Recovery and Development and the African Initiative to Fight Malaria in the 21st Century. This initiative led to the 'Roll Back Malaria' project in 1998, approved by African Heads of State and Government at the Abuja (Nigeria) summit on 25 April 20oo. In the Declaration and Plan of Action they adopted on this occasion, African leaders pledged to '[h]alve the malaria mortality for Africa's people by 2010' and called upon the United Nations (UN) to proclaim the decade 2001-2010 a 'Decade against malaria.' ${ }^{2}$ At the followup summit in April 2001, the heads of state and government of the OAU addressed HIV/AIDS, tuberculosis and other infectious diseases. They adopted a Declaration in which they considered HIV/AIDS a "state of emergency" and pledged to make the fight against this pandemic their top priority, devoting to it at least $15 \%$ of the budget of their national development plans. ${ }^{3}$ Despite the efforts made by several governments in this regard, this objective was rarely achieved with long-lasting results. For example, in 2010, a decade after the adoption of the Declaration, only five countries had reached or exceeded the $15 \%$ threshold. They were Rwanda (23.3\%), Malawi $(18.5 \%)$, Zambia (16\%), Burkina Faso (15.7\%) and Togo (15.4\%). ${ }^{4}$ At the 2013 follow-up

2 OAU, 'La Déclaration d'Abuja sur le projet «Faire reculer le paludisme en Afrique »', Abuja, 25 April 2000, 1-2). As will be discussed, the countries that have been hit hardest by Ebola are among those that had a very low budget allocated to the health sector.

3 Vincent Nwanma, 'Priorité à la lutte contre le sida' (2001) 15/1-2 Afrique Relance, 6.

4 Masimba Tafirenyika, 'Ebola sonne le réveil des dirigeants. La maladie met au grand jour les faiblesses des systèmes de santé laissés à l'abandon' (2014) 28/3 Afrique Renouveau, 11. 
summit, $\mathrm{AU}$ heads of state and government made institutional decisions to establish an African centre for disease prevention and control. ${ }^{5}$

As can be seen, normative action relating to HIV/AIDS and related diseases underwent significant developments during the decade 2001-2010. This can be seen with the developments at the UN, where, following the initiative of the African states, both the General Assembly and the Security Council intensified the debate on the issue of HIV/AIDS in Africa. When considering this issue in the context of UN peace-keeping operations in Africa on 10 January 2000, the Security Council considered that HIV/AIDs had implications for international peace and security. ${ }^{6}$ This approach set an important precedent for Council resolution 2177 (2014), which identified the Ebola virus fever epidemic as a threat to international peace and security. ${ }^{7}$

\subsection{The African Commission on Human and Peoples' Rights}

At its 29th session held in Tripoli (Libya) and Sirte (Libya) from 23 April to 7 May 2001, the African Commission on Human and Peoples' Rights (ACH PR), a subsidiary organ of the AU and one of the two main safeguard organs of the African Charter on Human and Peoples' Rights, adopted a resolution on "the HIV/AIDS pandemic, threat to human rights and humanity", under which it declared that this pandemic was a 'human rights issue' and called upon the African governments as well as international pharmaceutical industries and other international partners to allocate adequate resources to address it through funding research and development projects. ${ }^{8}$

In addition, within the framework of its special procedures, in particular the Working Group on Economic, Social and Cultural Rights, in May 2010 the

5 AU, 'Déclaration du sommet spécial de l'Union africaine sur le VIH/Sida, la tuberculose et le paludisme. Engagements d'Abuja pour l'élimination du VIH/Sida, de la tuberculose et du paludisme en Afrique d'ici à 203o', Abuja, Nigeria, 16 July 2013, Doc. SA10389, 8.

6 Michael Fleschmann, 'La prévention du sida à l'armée. L'ONU fait participer les casques bleus à la guerre contre le sida' (2001) 15/1-2 Afrique Relance, 16; on these developments, see Hélène de Pooter, Le droit international face aux pandémies: vers un système de sécurité sanitaire collective? (Pedone 2015).

7 UNSC Resolution 2177 (2014), 18 September 2014. See Alison Agnew, 'A Combative Disease: The Ebola Epidemic in International Law' (2016) 39 Boston College International \& Comparative Law, 98.

8 The African Commission on Human and People's Rights, meeting at its 29th Ordinary Session in Tripoli, the Great Socialist Peoples' Libyan Arab Jamahiriya from 23rd April to 7 th May 2001, 53 Resolution on the HIV/AIDS Pandemic - Threat Against Human Rights and Humanity ACHPR/Res.53(XXIX)o1, available at <https://www.achpr.org/sessions/resolutions?id=58>, last accessed (as any subsequent URL) on 17 May 2021. 
ADHP Commission established a Committee on the Protection of the Rights of People Living with HIV (PLHIV), and Those at Risk, Vulnerable to and Affected by HIV. ${ }^{9}$ The Committee has already carried out missions to several African countries and organized regional seminars and consultations on the promotion of the human rights of PLHIV and groups at risk. On the basis of its various activities, and with the support of the Joint United Nations Programme on HIV/AIDS (UNAIDS), the United Nations Development Program (UNDP) and several non-governmental organizations working in the fight against HIV/ AIDS, the Committee drew up a study on 'HIV, the Law and Human Rights in the African Human Rights System: Key Challenges and Opportunities for Rights-Based Responses.10 This study documents good national practices in protecting the rights of PLHIV and makes recommendations for the application of the human rights-based approach to health in HIV/AIDS programs. This approach requires the adoption of these programs to be inclusive, nondiscriminatory and to pay particular attention to the most vulnerable people, women and children and, above all, to set the ultimate objective of recognition by the States concerned of human rights as enshrined in the African Charter on Human and Peoples' Rights and international and regional human rights instruments, including the right to health.

\subsection{The African Union}

While continuing the normative efforts initiated by the OAU, the AU undertook to develop normative action in response to two new pandemics that hit the African continent, including the Ebola Virus Disease (EVD) and CovID-19. As a subsidiary body of the AU in the field of human rights, the African Commission on Human and Peoples' Rights has also developed guidance for compliance with international human rights law by Member States and other actors.

\subsection{1 $\quad$ Ebola Virus Disease}

On 8 September 2014, the Executive Council (Council of Foreign Ministers) of the AU adopted a decision on the Ebola outbreak, under which it requested the Member States to remove restrictions on the movements of people and the $\mathrm{AU}$ Commission to accelerate the establishment of an African Centre

Ibid., Committee on the Protection of the Rights of People Living with HIV (PLHIV), and Those at Risk, Vulnerable to and Affected by HIV, available at <https://www.achpr.org/ specialmechanisms/detail?id=15>.

10 African Commission on Human and Peoples' Rights, 'HIV, the Law and Human Rights in the African Human Rights System: Key Challenges and Opportunities for Rights-Based Responses', January 2018. 
for Disease Control and Prevention (ACDCP), pursuant to Assembly Decision AU/Dec.499 (XXII). ${ }^{11}$

This decision of the AU Executive Council was important in more ways than one. It struck a balance between respect for human rights, including freedom of movement and the right to non-discrimination, and recognition by member states of their prerogative to strengthen control, detection, and alert measures. This decision also had certain effects, as illustrated for instance by the fact that around twenty African countries that had previously adopted measures to ban travel from countries affected by the Ebola epidemic have withdrawn or revised them. This was the case for the member states of the Southern African Development Community (SADC), which lifted and/or amended the restrictions on the movements of people coming from the affected countries in April 2015. ${ }^{12}$

For its part, the ADHP Commission adopted a declaration on the spread of the Ebola virus on 11 September 2014, three days after the aforementioned decision of the AU Executive Council, according to which it called on the Member States to open their borders to facilitate access to the affected populations and to cooperate with the $\mathrm{AU}$, the $\mathrm{WHO}$ and other relevant international and national partners to address the lingering impact of the prevention and treatment measures on the economic, social and cultural rights of the affected people..$^{13}$

\subsubsection{Covid-19}

As an infectious disease, CoviD-19 has strong implications for human rights. Firstly, most states facing it have adopted health emergency measures, which severely restrict individual freedoms. Indeed, it cannot be ruled out that some of these measures, when the time comes, may be the subject of legal recourse before the African Commission and Court on Human and Peoples' Rights.

On 28 February 2020, the Commission issued a press release expressing its concern about the pandemic and urging States to take measures, including

\footnotetext{
11 AU, Decision on The Ebola Virus Disease (EVD) Outbreak, Doc. Ext./EX. CL/Dec. 1 (XVI), 8 September 2014, 1-3.

12 Regional Network for Equity in Health in East and Southern Africa (EQUINET), 'African Response to the 2014/5 Ebola Virus Disease Epidemic', Discussion Brief, October 2015, 10-11.

13 Ibid., 'Déclaration de la Commission africaine des droits de la Commission africaine des droits de l'homme et des peuples sur la propagation du virus Ebola', Banjul, 11 September 2014, 1-2.
} 
preventive measures, to combat it. ${ }^{14}$ On 24 March 2020, the President of the African Commission on Human and Peoples' Rights, in a press statement on an effective human rights-based response to Covid-19 in Africa, recalled the principles that should guide the States in adopting measures to combat this pandemic, including: (1) The principle of legality; (2) Non-discrimination and equality; (3) Access to information; (4) Primacy of timely preventive and containment measures; (5) Addressing challenges of non-implementation and compliance; (6) Protection of vulnerable groups; (7) Prisons and other places of detention; (8) The right to health; (9) Solidarity and duty of individuals, private sector, community leaders, media and religious institutions; (10) Respect for human and peoples' rights; (11) Mitigation measures; (12) Monitoring, investigation and corrective measures. ${ }^{15}$

In addition, at least two special committees of the African Commission on Human and Peoples' Rights issued statements concerning the implications of certain measures adopted in the context of the CoviD-19 pandemic for respect for human rights and fundamental freedoms falling within their mandates. This is the case with the Special Rapporteur on prisons, conditions of detention and police action in Africa. According to a press release dated 22 April 2002, there have been reports of excessive use of force by police in the fight against COVID-19. ${ }^{16}$

On the same day, the Special Rapporteur on Prisons, Conditions of Detention and Police Action in Africa issued a second press release on the release of prisoners in the same context. In it, the Special Rapporteur noted with satisfaction that detainees had been released in several African states, including Algeria, Burkina Faso, Cameroon, Ethiopia, Kenya, Libya, Mozambique, Niger, Nigeria, Uganda, DRC, Senegal, Sudan and Tunisia. The Special Rapporteur called on African states that have not yet done so to take similar measures in accordance with the Declaration of 24 March 2020 on human rights-based responses to COVID-19 in Africa. ${ }^{17}$

14 African Commission on Human and Peoples Rights, 'Press Statement of the African Commission on Human \& Peoples' Rights on the Coronavirus (CoviD-19) crisis', Banjul, 28 February 2020 available at $<$ https://www.achpr.org/pressrelease $/$ detail?id=48o $>$.

15 Ibid., 'Press Statement on human rights based effective response to the novel COVID-19 virus in Africa', Banjul, 24 March 2020, available at <https://www.achpr.org/pressrelease/ detail id $=483>$.

16 Ibid., 'Press Release of the Special Rapporteur on Prisons, Conditions of Detention and Policing in Africa on Reports of Excessive use of Force by the Police during the COVID19 Pandemic', Banjul, 22 April 2020, available at <https://www.achpr.org/pressrelease/ detail?id $=491>$.

17 Ibid., 'Press Release of the Special Rapporteur on Prisons, Conditions of Detention and Policing in Africa on the Release of Prisoners during the COVID-19 Pandemic', 17 April 2020, available at <https://www.achpr.org/pressrelease/detail?id=492>. 
For its part, the Working Group of the Commission on the Rights of Indigenous Populations issued a press release on 23 April 2020 in which it expressed concern at the precarious situation of these populations and communities, their inaccessibility to information about COVID-19 and the negative impact of movement restrictions imposed by states on their pastoral activities. ${ }^{18}$

On 8 March 2021, the Special Rapporteur on Refugees, Asylum Seekers, Internally Displaced Persons and Migrants in Africa of the African Commission on Human and Peoples' Rights joined several other relevant universal and regional human rights mechanisms, including the UN Committee on Migrant Workers (CMW), the UN Special Rapporteur on the human rights of migrants and the Office of the United Nations High Commissioner for Human Rights (OHCHR), the Special Representative of the Secretary General on Migration and Refugees of the Council of Europe and the Rapporteur on the Rights of Migrants of the Inter-American Commission on Human Rights, in adopting a Guidance Note on Equitable Access to COVID-19 vaccines for migrants and their families. The participating mechanisms reaffirmed the right of the latter to access to health facilities and services in an equitable and non-discriminatory manner. They also urged States to develop coordinated strategies and cooperation and assistance mechanisms to address the obstacles to access to the vaccines by the populations of poor countries. ${ }^{19}$ The African contribution to this joint guidance note reflects the practice developed so far by African regional organizations at institutional and operational levels.

\section{Institutional Aspects: The Examples of the WAHO and AU}

At sub-regional level, the first health organizations tasked to address epidemics were established in the immediate aftermath of independence. In this context, in 1962 the Central African States established the Organisation de la coopération pour la lutte contre les grandes endémies en Afrique centrale. In West Africa, Francophone countries created the Organisation commune de lutte contre les grandes endémies (OCGE), while the Anglophone countries, with the support of the Secretariat of the Commonwealth, in 1978 established the West African Health Community (WAHC). In 1987, following the establishment of the ECOWAS, OCGE and WAHC were merged into a single entity, the West

18 Ibid., 'Press Release on the Impact of the COVID-19 Virus on Indigenous Populations/ Communities in Africa', Banjul, 23 April 2020, loc. cit.

19 See 'Joint Guidance Note on Equitable Access to Covid-19 Vaccines for All Migrants', 8 March 2021, at <https://JointGuidanceNoteCOVID-19-Vaccines-for-Migrants.pdf> (ohchr.org). 
African Health Organization (WAHO), the main and operational sub-regional health organization in Africa. The AU recently implemented the OAU's recommendation to create a Regional Centre for Disease Control and Prevention in establishing the Africa CDC. The latter, in close cooperation with the RECs, has developed a new African health governance architecture including the RCCs established in close coordination with the CDC.

\subsection{The WAHO (ECOWAS)}

In 1987, the ECOWAS established the WAHO as its specialized health agency. The latter was tasked to facilitate the development of cooperation among its member states in response to diseases. When West Africa faced the Ebola Virus Disease (EVD) from 2014 to 2016, the WAHO served as the operational body to respond to this epidemic. However, the WAHO demonstrated limited technical, human and financial capacities to address the EVD. The creation of WAHO in 1987 was perceived as a good practice and set a precedent in the field of transboundary and regional health governance. Hence, when the Ebola outbreak became public in March 2014, EcowAS was able to initiate a series of actions against the disease [...] According to the EcowAs, "[i]n response to this worrisome situation and upon recommendation by the Extraordinary Meeting of the Assembly of Health Ministers (AHM) held on 28 August 2014 in Accra, Ghana, EcowAs developed and implemented a regional-sectorial plan on Ebola control' (ECOWAs, 'Ebola Virus (EVD) Epidemic Control in the ECOWAS Region', Abuja, January 2017, pp. 1 and $5^{-6}$ ). However, it appeared that the WAHO was not equipped to respond to a crisis comparable to the EVD epidemics. Instead, the ECOWAS-RCSDC was established to assist States facing the most important and deadly EVD epidemic from 2014 to 2016 . The founders of the Regional Centre largely took into account the lessons learned from this experience. For instance, a Rapid Response Team was established as part of the RCSDC to address the delay that occurred during the WAHO intervention in the EVD crisis. ${ }^{20}$

In the context of the development of the regional collaborating centres of the Africa Disease prevention and Control Centre under the leadership of the African Union, the EcowAS established a Regional Centre for Surveillance and Disease Control (RCSDC) and placed it under the supervision of the waHo. The decision to establish the regional collaborating centre for West Africa was

20 See Mutoy Mubiala, 'Regulations C/REG. 11/12/15 Establishing and Stating Operating Procedures of the ECOWAS Regional Centre for Surveillance and Disease Control (ECOWAS-RCSDC)', 14 December 2015, Oxford International Organizations 467 (updated on 17 April 2019), 2. 
first taken by the Final Communique adopted by the Ecowas Authority of Heads of State and Government in Accra in May 2015. In a follow-up and in accordance with this Final Communique, the EcowAs Council of Ministers adopted with a decision, on 14 December 2015, the Regulations and Operating Procedures of the ECOWAS-RCSDC. Its headquarters were officially inaugurated in February $2008^{21}$ and set-up with the support of the Nigeria Centre for Disease Control. The ECOWAS-RCSDC was one of the five regional collaborating centres RCC of the Africa CDC (see below).

The ECOWAS-RCSDC was the first regional collaborating centre to be visited by the Africa CDC in Abuja, in June 2017. During this meeting, the two entities reached a consensus on the governance architecture of the RCSDC and the priority public health activities to be carried out in West Africa. Participants in the meeting adopted, in particular, the concept of a 'One Health Approach', according to which they commit to develop three levels of coordination including integrated management guidelines, training and advocacy. ${ }^{22}$ In practice, the RCSDC demonstrated a low level of operationalization and was absorbed by the WAH O, as illustrated by the active intervention of the latter in response to the on-going COVID-19 pandemic. As a consequence, the establishment of the ECOWAS-RCSDC has not contributed to the expected development of coordination between the AU and the RECs in the field of pandemic control and prevention, through the architecture of the Africa CDC and its RCCs. ${ }^{23}$

\subsection{The Africa $\operatorname{CDC}(\mathrm{AU})$}

Apart from its normative and advocacy roles, over the years the AU has not acted as a specialized health body. The situation evolved at the beginning of 20oos, when the AU Assembly repeatedly requested the AU Commission to consider the project to establish such a mechanism. The AU established the Africa Centres for Disease Control and Prevention (Africa CDC) as its specialized body in the field of health governance in accordance with a decision adopted by the Assembly of Heads of State and Government on 31 January 2016. ${ }^{24}$

21 See 'ECOWAS Opens Regional Centre for Surveillance and Disease Control in Abuja', Premium Times, 21 February 2018, <https://www.premiumtimesng.com/foreign/west -africa-foreign/259411-ecowas-opens-regional-centre-surveillance-disease-control-abuja .html>.

22 Africa CDC, 'Report of West Africa CDC Regional Collaborating Centre Meeting, Abuja, Nigeria, 22-23 June 2017, 7 .

23 Jens Herpolsheimer, 'Working Paper: ECOWAS and the Covid-19 Pandemic: Regional Responses and Inter-Regional Cooperation', ReGentGlobe Working Paper $\mathrm{N}^{\circ}{ }_{2} \mathrm{O}$, April 2000, 15-16.

24 Adoption of the Statute of the African Centre for Disease Control and Prevention (Africa CDC) and its Framework of Operation (31 January 2016), Assembly/AU/Dec. 589 
The Africa CDC is located in Addis Ababa (Ethiopia), at the Headquarters of the $\mathrm{AU}$ and it was launched in January 2017.

In terms of its mandate and structure, the main objectives of the Africa CDC include:

a) The establishment of early warning and response surveillance platforms to address all emergencies in a timely manner; b) Supporting public health emergency preparedness and response; c) Assisting Member States in collaboration with wHO and other stakeholders to address gaps in International Regulations compliance [article 3 (a), (b) and $(\mathrm{c})] .{ }^{25}$

According to its Statute, the operations of the Africa CDC are guided by the following core principles:

1) Leadership; 2) Credibility; 3) Ownership; 4) Delegated authority; 5) Timely dissemination of information;6) Transparency; 7) Accountability; and 8) Value added [Article 4]. The framework of the Africa CDC is based on the assumption that the latter adds value and is highly credible and shall operate in collaboration with Regional Centers in the pursuit of its strategic objectives. ${ }^{26}$

Subsequent to its launch and start of operations, the African CDC helped to establish its Regional Collaborating Centres (RCCs), where relevant, in due cooperation and with the support of the Regional Economic communities (RECS), in the five political regional regions of the AU, including Central Africa (Libreville, Gabon); East Africa (Nairobi, Kenya); North Africa (Cairo, Egypt); Southern Africa (Lusaka, Zambia); as well as West Africa (Abuja, Nigeria). ${ }^{27}$

In addition to its RCCs, the Africa CDC is tasked with the mandate to develop a partnership with the World Health Organization for the effective implementation of the 2005 International Health Regulations, with a view to

(XXVI). For the comments, analysis and text of the Statute of the CDC, see Mutoy MUBIALA, 'Statute of the Africa Centres for Disease Prevention and Control (Africa CDC), 31st January 2016' (2018) 392 Oxford International Organisations (OxIO) 1-19.

Ibid., 3 .

26 Ibid., 4-5.

27 Mubiala (n 24) and 'Regulations Establishing and Stating Operating Procedures of the ECOWAS Regional Centre for Surveillance and Disease Control (ECOWAS-RCSDC), 2019, OxIO, 467 . 
contributing to the strengthening of national health institutions in Africa. ${ }^{28}$ This trend has had a positive impact on the Africa CDC's interventions on the ground.

\section{4}

\section{Operational Aspects}

The Ebola outbreak in West Africa provided the opportunity for the AU to deploy a support mission and to establish an African Health Voluntary Corps. This happened after the AU developed a new doctrine in the field of international cooperation through the adoption of the African Solidarity Initiative (ASI) or 'Africa Helping Africa' in 2012, according to which it called on African States and people to take a leadership role in supporting the countries emerging from conflicts or in a post-conflict situation. This new paradigm gave rise to an emerging principle of "Responsibility to Assist", which was implemented for the first time in the context of pandemic responses, including the Ebola outbreaks in West Africa and the DRC, as well as the on-going CovID-19 pandemic.

\subsection{The African Solidarity Initiative and the Emerging Principle of "Responsibility to Assist"}

As is well known, Africa has historically developed the tradition of assistance, not only for members of the group to which an individual belongs but also for peoples from other communities, including refugees. This social practice was considered as a binding customary norm and those who violated it were punished or excluded from their community. As a legacy of this traditional rule, it was reflected in several postcolonial regional instruments. To give a few examples, the Organization of the African Unity (OAU) 1969 Convention on Specific Aspects of Refugees in Africa stated in article 2, paragraph 4, that:

When a Member State finds difficulty in continuing to grant asylum to refugees, such Member State may appeal directly to other Member States and through the OAU, and such other Member States shall, in the spirit of African solidarity and international cooperation, take appropriate measures to lighten the burden of the Member State granting asylum.

Furthermore, in accordance with the 1981 African Charter on Human and Peoples' Rights, the individual has duties towards the family, society, the State and the international community (Article 27), including 'the duty to contribute

28 Ibid., 4. 
to the well-being of his family, to solidarity, to the preservation and strengthening of positive African cultural values in his relations with other members of the society [...], to contribute to the promotion of the moral well-being of society' (Article 29).

More recently, the policy organs of the AU, the Assembly of the Heads of State and Government and the Executive Council, adopted in July 2012 the Declaration entitled 'African Solidarity Initiative' (ASI), also identified as "Africa Helping Africa", aimed at mobilizing continental support to countries emerging from conflicts. ${ }^{29}$

The ASI provides a foundation for an emerging principle of "Responsibility to Assist" grounded on African traditions..$^{30}$ This novel principle could be defined as 'the duty of the international community to assist the countries in need of support in the context of pandemics/outbreaks, in particular when the latter spread in the world'. The "Responsibility to Assist" would supplement the primary responsibility of the State to address the said pandemics/outbreaks. This principle was initially implemented in the context of African response to recent pandemics.

The implementation of the "Responsibility to assist" in pandemics is illustrated by three case studies including the AU's intervention in the Ebola outbreak in West Africa from 2014 to 2016, African support in response to three successive Ebola outbreaks in the DRC from 2018 to 2020 , as well as the application of the "Africa Helping Africa" watchdog in the context of response to the global/regional covid-19 pandemic. ${ }^{31}$

\subsection{The ASEOWA and the AHVC}

From 2014 to 2016, several West African countries faced the Ebola Virus Disease (EVD) for their first time. While the Economic Community of West African States (ECOWAS) speedily reacted to this pandemic, in particular in the most affected countries including Guinea, Liberia and Sierra Leone, it subsequently relied on the African Union's support. The ASEOWA benefited from considerable support from the AU Member States, the African private sector, as well as Africans. For the first time in Africa's history, African voluntary contributions

29 AU, 'African Solidarity Initiative in Support for Post-Conflict Reconstruction and Development in Africa. Concept Note', Addis Ababa, 2012.

30 On the novel concept of a 'Responsibility to Assist', see Mutoy Mubiala, 'L'Union africaine', in Sandra Szurek, Marina Eudes et Philippe Ryfman (eds), Droit et pratique de l'action humanitaire, Paris, Libraire générale de droit et de jurisprudence (2019) 386-387, and Mubiala, 'Le rôle des organisations régionales africaines ...' (n 1 ) 412-413.

31 Regional Network For Equity in Health in East And Southern Africa (EQUINET), 'African Responses to the 2014/5 Ebola Virus Disease Epidemic', Discussion Brief, October 2015, 6. 
amounted to USD 19,500 million, exceeding those provided by developed countries (USD 14 million). Moreover, African states seconded more than 800 health workers as volunteers to ASEOWA, in addition to 86 volunteers who individually responded to the AU's Commission call in August and September 2014. ${ }^{32}$ This led to the establishment of the 'African Health Volunteers Corps', which has become the operational arm of the Africa CDC. ${ }^{33}$

The AU's intervention in the response to the Ebola outbreak in West Africa played the role of catalyst and accelerator in the establishment of the longawaited Africa Centre for Disease Prevention and Control (Africa CDC) and its regional collaborating Centres (RCCs).

\subsection{The Africa CDC and Responses to Pandemics in Africa}

During its four first years of operation (2017-2020), the Africa CDC deployed team missions to assist several African countries in addressing disease outbreaks, including the DRC (Ebola and Cholera); Ethiopia (Acute Watery Diarrhea); Madagascar (Plague); Mozambique (Malaria); Namibia (Malaria); Nigeria (Lassa Fever, Meningitis and Monkey Pox), etc. ${ }^{34}$ In this regard, the Africa CDC has provided valuable contributions to addressing the three most recent EVD pandemics in the DRC.

$4 \cdot 3 \cdot 1$

African Support to Address the Ebola Outbreaks in the DRC (2018-2020)

Since 1976, the year of the first ever occurrence of the EVD in the DRC, this country has faced 11 outbreaks, three of which emerged over the past three years, in the province of Equador (Equateur) in the North-West (2018 and 2020 ), the North and South Kivus, and Ituri provinces, in eastern DRC. The Africa CDC was instrumental to the AU's support to the affected country. It is important to note that the Africa CDC's intervention in eastern DRC was hampered by the insecurity prevailing in this area. Amid this hostile environment, the Africa CDC was able to provide valuable support to the DRC to address the three EVD outbreaks.

32 AU, 'Addendum to the Report of the Commission on the Ebola Virus Disease (EVD) and the Implementation of the Decisions of the 16th Extraordinary Session of the Executive Council on Ebola', Doc. EX. CL/867 (XXVI), Addendum, January 2015, 1-2.

Medical Brief, 1 June 2016, <https://www.medicalbrief.co.za/archives/african-health -volunteers-corps-joins-raft-continental-health-actors/>. See also wHo, 'Regional strategy for health security and emergencies 2016-2020', Document AFR/RC66/6), 13 June 2016, 9.

$34 \mathrm{AU}$, 'First Progress Report of the Chairperson of the Commission on the Africa Center for Disease Control', 24 March 2018, 5-8. 
As of June 2019, the Africa CDC was able to report the following achievements:

- Training more than 800 local health care workers and community volunteers in disease surveillance, laboratory diagnosis, risk communication and infection prevention and control;

- Provision of laboratory services: six GemExpert machines and more than 3000 cartridges, as well as supporting laboratory diagnostic services in 6 health zones, including the 4 fully run by the Africa CDC;

- Contact tracing and surveillance: registration of more than 127,00o people as contacts in the health zones, involvement of 17 epidemiologist and 8 infection prevention experts in finding and following up cases and contacts, and monitoring field operations and missions;

- Infection prevention and control: tracing of 469 health care workers, traditional healers and teachers; supply of personal protection equipment to 19 health centres and hospitals; evaluation of the state of hygiene in health centres and provision of handwashing facilities in schools and churches; and production of a video on handwashing, broadcast on national television and other media;

- Cross-border surveillance: screening of more than 7 million people at border crossings, tracing of 350 individuals in point of entry screening in partnership with the ministry of public health;

- Vaccination: mobilization and vaccination of nearly 136 ,ooo contacts. ${ }^{35}$

At the end of the third Ebola outbreak, in the Equateur province, in November 2020 , the Africa CDC reported the following:

The Minister of Health of the Democratic Republic of Congo (DRC), H.E. Dr Eteni Longondo, today declared an end to the 11th Ebola Virus Disease (EVD) outbreak in the North-Western Province (Equateur) of the country, five months after the outbreak began.

'The ability of the DRC Government and partners to quickly and effectively bring an end to the 11th Ebola outbreak is a remarkable milestone, especially at this time that the world is struggling to overcome the COVID-19 pandemic', said H.E. Moussa Faki Mahamat, Chairperson of the African Union Commission. 'I commend the resolute determination and coordinated effort of all the partners, healthcare workers and community members who have worked together to ensure an Ebola-free DRC. Their courage and gallant sacrifices will always be remembered'.

35 AU/Africa CDC, 'Africa CDC Response to Ebola in DR Congo', Emergency Response Digest, vol. 1 (1), June 2019, 1. 
The outbreak was reported in 13 health zones in the affected province, with a total of 130 cases, 55 deaths (case fatality rate $42.3 \%$ ) and 75 recoveries, including two healthcare workers who lost their lives while caring for EVD patients. The 11th outbreak started while the country was still responding to the 1oth outbreak in the Eastern Provinces of Kivu and Ituri. The government had declared the outbreak on 1 June 2020, few weeks before declaring an end to the 1oth outbreak and two months into the CoviD-19 outbreak.

The African Union Commission, through the Africa Centres for Disease Control and Prevention (Africa CDC), had deployed frontline workers and other personnel to support response to the roth outbreak and some of them were also involved in planning the national response to the 11th outbreak. Through the Africa CDC ECHO platform, the Africa CDC team at headquarters and the Regional Collaborating Centres supported knowledge and information sharing sessions to prevent crossborder transmission and prepare neighbouring countries for immediate and active response if such transmission occurs.

'The DRC has shown good example by applying the knowledge gained from previous outbreaks to quickly fight and bring the 11th outbreak to an end. Africa CDC will continue to work with the Government of DRC and other partners to better coordinate our efforts in strengthening health systems in the DRC and across Africa,' said Dr John Nkengasong, Director of Africa CDC.

'The people of DRC recognize the support of the African Union through Africa CDC as well as other partners that have invested technical and financial resources to end the 1oth and nth outbreaks. We will ensure that these investments are effectively harnessed by preventing as much as possible a re-emergence of Ebola outbreaks in the DRC', said Dr Longondo. ${ }^{36}$

Apart from the Africa CDC's collective support to the DRC, several African countries provided assistance to the latter at bilateral level. For example, Guinea deployed dozens of health care workers in the affected areas. One should remember that the DRC deployed dozens of health volunteers to Guinea during the Ebola outbreak in West Africa, from 2014 to 2016. This cross-cutting assistance illustrates the legacy of the African historical tradition of 'mutual aid', thus contributing to the crystallization of the principle of "Responsibility

36 Ibid., 'Democratic Republic of the Congo Celebrates End of 11th Ebola Virus Disease Outbreak', 18 November 2020. 
to Assist" at the African regional level, as other practices illustrate this trend in the context of the African response to the ongoing COVID-19 pandemic.

$4 \cdot 3 \cdot 2$

The Africa CDC's Coordinating Role in the African Response to the COVID-19 Pandemic

Since 2019, the world has been affected by the COVID-19 pandemic. Africa as a region did not escape this dynamic. As of early 2O20, the Africa CDC has taken on several initiatives and measures to enable the AU, on the one hand, and Member States, on the other, to respond to the global coviD-19 pandemic at regional and national levels. These initiatives include, among others, the establishment of a Task Force for COVID-19 (ATFCOR), the joint AU Commission/ Africa CDC Partnership to Accelerate COVID-19 Testing (PACT)/Trace, Test and Track (T-3), with the objective to test 20 million Africans by the end of 2020 , as well as support for the adoption of a Joint Continental Strategy for COVID-19 by the African Ministers of Health, in February 2020. This Strategy has been implemented through the ATFCOR and the Africa CDC, with the support of the African Volunteers Health Corps.

Moreover, the Africa CDC has played the role of continental focal point in relation to external regional and global actors. In this context, it has interacted with actors including multilateral organizations such as WHO, GAVI and WFP; it has managed and coordinated foreign medical aid, including support received from external private donors such as the Jack Ma Foundation; it also co-hosted a special webinar entitled 'Global Medixchange'. ${ }^{37}$ On 7 December 2020, the Africa CDC, on behalf of the AU Commission, signed a cooperation agreement with the European Union Commission. According to the media,

Today, the European Centre for Disease Prevention and Control (ECDC) and the Africa Centre for Disease Control and Prevention (Africa CDC) launched a new partnership initiative to strengthen the capacity of Africa CDC to prepare for and respond to public health threats in Africa. The four-year project, 'EU for health security in Africa: ECDC for Africa CDC', funded by the EU, will also facilitate harmonised surveillance and disease intelligence, and support the implementation of the public health workforce strategy of Africa CDC. ${ }^{38}$ 
Also, the Africa CDC has been preparing the holding of the first international conference on public health in Africa, scheduled for May 2021. ${ }^{39}$

The intervention of the Africa CDC supplements the national responses of the African States, including health policies promoting the principle of "Responsibility to Assist" in African inter-state cooperation in responding to the COVID-19 pandemic. As this author wrote, elsewhere,

In response to Covid-19, contrary to other continents, the dynamics of transnational solidarity among African countries has been widely identified as good practice. The trend of solidarity among African States and peoples was recently illustrated by the holding of bilateral videoconference meetings between President Rajoelina of Madagascar and several African Heads of State, including the Presidents of the DRC and Senegal, about a medicine developed by the Malagasy Institute of Applied Research. In early May 2020, the government of Madagascar donated consignments of the medicine to several African countries, including Central African Republic, Niger, the Gambia, Equatorial Guinea, Guinea Bissau, the DRC as well as the Republic of the Congo. Pending the testing of this medicine by the wHo's relevant expert bodies and without anticipating the outcome, this brief suggests that its no-cost sharing by Madagascar with other African countries contributes to the implementation of the new 'Africa Helping Africa' paradigm and to the tentative crystallization of an emerging principle of ' $\mathrm{R} 2 \mathrm{~A}$ ' at the regional level.

For its part, at the request of the Africa CDC, the DRC has deployed 37 public health experts to provide support to four other African countries, including Burkina Faso, Cameroon, Mali and Niger. ${ }^{40}$

In mid-June 2020, Morocco dispatched medical equipment, including masks and tests, for distribution to 15 African countries, including Burkina Faso, Cameroon, Chad, DRC, Mauritania, Niger, Republic of the Congo, and Senegal. ${ }^{41}$ Elsewhere, Cuba provided medical support to some European and African countries, including Italy, Spain and South Africa, thus anticipating the potential for the universal implementation of the "Responsibility

$39 \quad$ Ibid.

40 See Mubiala, 'The African Union and the Covid-19 Pandemic' (n 1) 3 (references omitted).

41 'Coronavirus: le Maroc joue la diplomatie «du masque» vers l'Afrique subsaharienne', Le Monde, 15 June 2020, <www.lemonde.fr/Afrique/article/2020/06/15/corona virus-le-maroc-joue-la-diplomatie-du-masque-vers-l-afrique $>$. 
to Assist". This leads to the issue of the relevance of international law in this regard.

\subsubsection{The Africa CDC's Role in Global Governance in Pandemics}

By adopting the Declaration of the African Initiative Solidarity (ASI), also identified as 'Africa Helping Africa', in July 2012, the AU gave rise to an emerging principle of "Responsibility to Assist", compliant with the African Tradition of 'mutual aid'. This emerging principle was initially - and is currently implemented in the context of responses to pandemics in Africa, including the Ebola outbreaks (West Africa from 2014 to 2016, and the DRC from 2018 to 2020) as well as the ongoing global COVID-19 pandemic.

Since the occurrence of the COVID-19 pandemic and the search for solutions to address it, there has been a debate on the application of the 'global public goods' concept to the COVID-19 vaccines and other medicines. On 19 May 2019, the wHO Assembly adopted a resolution recommending, inter alia, universal, timely and equitable access to all health products and technologies and the urgent removal of obstacles to this access. ${ }^{42}$ The rationale of this recommendation was to address concerns about the national self-reliance policies promoted by the Trump administration in the United States of America (USA). Further, the recommendation was to promote an equitable distribution of vaccines for effective global protection against coviD-19.

To solidify the 'global public goods' approach to vaccination against CoviD-19, a pioneer entity in public-private partnership in this field, the Global Alliance for Vaccines and Immunization (GAVI), launched the covID19 Vaccines Advance Market Commitment (COVAX AMC) with the overall objective to ensure fair and equal access to CoviD-19 vaccines for low-and middle-income economies. According to its mission statement,

At the Global Vaccine Summit on June 4, GAVI launched the CoviD-19 Vaccines Advance Market Commitment (COVAX AMC) as the first building block of the COVAX Facility. The GAVI COVAX AMC is the innovative financing instrument that will support the participation of 92 low- and middle-income economies in the covax Facility - enabling access to donor-funded doses of safe and effective Covid-19 vaccines. The AMC, combined with additional support for country readiness and delivery, will make sure the most vulnerable in all countries can be protected in the short term, regardless of income level. ${ }^{43}$

42 who, Covid-19 Response, A/73/3, 19 May 2019.

43 'What is the Gavi COVAX AMC?', available at <www.gavi.org/gavi-covax.amc>. 
An initiative such as the covax Facility, implemented in close cooperation with the WHO and UNICEF, is able to contribute to the universal implementation of the principle of "Responsibility to Assist". It encompasses legal aspects (fair and equal/equitable access) relevant to the rights-based approach to international health cooperation, as discussed above. At the virtual G-20 summit in November 2020, chaired by Saudi Arabia, participating States committed to recognise Covid-19 vaccines as 'global public goods'. As a consequence, they stated their support for their fair and equitable access by people across the world. The French President Emmanuel Macron then stated that Covid-19 vaccine 'grabbing' in developed countries will have a counter-productive impact if the other regions, in particular Africa, are excluded from their distribution. Despite this political commitment of the G-20, the UN Secretary-General Antonio Guterres expressed deep concerns about the under-funding of the covax Facility, as the funding then received was far from the budgeted US $\$ 24$ billion and called upon the G-20 to fill the existing gaps. ${ }^{44}$

As far as Africa is concerned, the Africa CDC has welcomed the covAX initiative and has been developing a 'Framework for fair, equitable and timely allocation of COVID-19 vaccines in Africa'. As reported by the latter,

The virtual conference, co-organised by the Africa Centres for Disease Control and Prevention (Africa CDC) and the South African Medical Research Council (SAMRC) brought together African leaders, public health professionals and researchers, policymakers, business leaders and civil society and community leaders. The objective was to discuss strategies and approaches to remove barriers to widespread delivery and uptake of effective covid-19 vaccines across Africa, guided by African voices and indigenous values. The goal of the conference was to provide input for a framework for fair, equitable and timely allocation of covid19 vaccines in Africa.

Dr John Nkengasong, Director of Africa CDC, welcomed the participants and thanked the South African Medical Research Council under Prof. Glenda Gray's leadership for the collaboration on this critical conference. Dr Nkengasong emphasized the urgent need to translate the preparation for COVID-19 vaccine deployment into action, as we are in

44 Agence France Presse, 22 November 2020, available at <www.lapresse.ca/internatio nal/2020-11-21/sommet-virtuel-du-g2o/appel-des-dirigeants-a-la-solidarite-sur-le>. 
the middle of the pandemic, and the vaccination campaigns have started. ${ }^{45}$

The covax Facility initiative is likely to reflect the first application of the African-based principle of "Responsibility to Assist" at global level. In addition, in the same vein, in January 2021, 'Gavi' (Global Alliance for Vaccines and Immunisation) adopted another initiative aimed at securing a global Ebola-vaccine stockpile for all countries in health emergency situations. According to Gavi,

A global emergency stockpile of 500,000 doses of Ebola vaccine, funded by Gavi, will be available to all countries for outbreak response following a procurement process concluded by UNICEF with a vaccine manufacturer. Gavi-eligible low-and lower middle-income countries will be able to access the stockpile free of charge and will receive support for operational costs to conduct outbreak response immunization activities. ${ }^{46}$

\section{$5 \quad$ Conclusion}

The above analysis shows that there is an emerging African regionalism in international health law and policy. At normative level, the AU adopted a series of instruments - both conventional and declaratory - to regulate health governance in Africa. In particular, the Statute of the Africa CDC provides that AU Member States must take the necessary measures to effectively implement the 2005 International Health Regulations. This has been complemented by a series of declarations adopted by various bodies of the AU requesting Member States to comply with international standards and norms, including in the field of human rights, in pandemic situations as illustrated by the recent Ebola and Covid-19 outbreaks. At institutional level, African regionalism is characterized by the development of a health governance architecture including both the AU (through the Africa CDC) and Regional Economic Communities (through the RCCs). In the particular case of West Africa, this architecture is likely to strengthen the existing capacities of the WAHO to address epidemics

45 AU/Africa CDC/SAMRC, 'Virtual Conference on Framework for Fair, Equitable and Timely Allocation of Covid-19 Vaccines in Africa', Highlights for Day 1, 16 December 2020, 1.

46 Gavi, '50o,ooo Doses of Ebola Vaccine to Be Made Available to Countries for Outbreak Response', 12 January 2021, available at $<$ https://www.gavi.org/news/media-room/500ooo -doses-ebola-vaccine-be-made-available-countries-outbreak-response >. 
and pandemics. Moreover, the new African health governance architecture has enabled the continent to better coordinate its responses to pandemics, as illustrated by its action during the on-going CoviD-19 pandemic, as well as implement the regional emerging principle of the "Responsibility to Assist".

This African regional principle has been instrumental for the African regional health organizations and their Member States in their responses to recent Ebola and COVID-19 pandemics on the continent. In particular, the intervention by the African Union, through its Centre for Disease Control and Prevention (Africa CDC), has been inspired and guided by the African Solidarity Initiative (also known as 'Africa Helping Africa'). African States and regional organizations have also advocated for the adoption of a similar cooperative approach based on solidarity in the North-Global South relationship. For the author of this paper, the Gavi Covax and Ebola Vaccine Stockpile initiatives are likely to implicitly reflect the African-based principle of "Responsibility to assist" at universal level. 